\title{
COMPARATIVE EVALUATION OF PYROGENS TESTS IN PHARMACEUTICAL PRODUCTS
}

\author{
Rosimar L. Silveira; Simone S. Andrade; Cleber A. Schmidt; Renata G. Casali; Sérgio L. Dalmora* \\ Departamento de Farmácia Industrial, Centro de Ciências da Saúde, Universidade Federal de Santa Maria, Santa Maria, \\ RS, Brasil.
}

Submitted: January 06, 2003; Returned to authors: July 25, 2003; Approved: March 04, 2004.

\begin{abstract}
A comparison of methodologies for detection of pyrogens in pharmaceutical products was performed. The rabbit pyrogen test was optimized and the dose-response curve was obtained for the $2^{\text {nd }}$ International Standard for bacterial endotoxins, establishing $13.81 \mathrm{EU} / \mathrm{mL} / \mathrm{kg}$ as the concentration of endotoxin necessary to induce a temperature rise of $0.5^{\circ} \mathrm{C}$. The $0.5^{\circ} \mathrm{C}$ cut-off was shown to give results that were more compatible with the pyrogenic doses for humans. The Limulus amoebocyte lysate test (LAL) was standardized with gel-clot and chromogenic endpoints, and used for the comparative evaluation of pharmaceutical products showing good agreement. The use of $\beta$-glucan-reactive and non-reactive LAL reagents identified some products with falsepositive results. The interference test was carried out and the specifications validated for some new products as the maximum valid dilution. The results emphasized the importance and limitations of the assays recommended for the evaluation of purity and quality control of parenteral medicinal products, improving the existing methodologies in the context of reduction and replacement in the use of animal models.
\end{abstract}

Key words: bacterial endotoxin, Limulus amoebocyte lysate, pyrogens, rabbit pyrogen test

\section{INTRODUCTION}

Pharmaceutical products intended for parenteral use must be free of pyrogens, which can originate from Gram-negative or Gram-positive bacteria, viruses and fungi. Endotoxins (Lipopolysaccharides, LPS) from Gram-negative bacteria are commonly found in parenteral pharmaceuticals and medical devices and are of particular concern to the pharmaceutical industry. Endotoxins are large molecular weight complexes $\left(\sim 10^{6}\right.$ Da) associated with, and shed from, the outer membranes of Gram-negative bacteria $(8,14)$. Endotoxins consist of three distinct chemical regions: a lipid moiety (lipid A) which is linked to a polysaccharide core that is, in turn, linked to O-antigenic side-chains $(8,18)$. Each endotoxin presents a composition and a variable structure that affects its function and biological activity; endotoxin functions include the induction of fever and acute phase proteins, headache and severe hypotensive shock.

There is good evidence that the fever response to various exogenous pyrogens (e.g. endotoxin) is mediated by endogenous pyrogens, i.e. pyrogens generated by the host. Endogenous pyrogens have potent pyrogenic and inflammatory activities and include interleukin $1-\alpha(\mathrm{IL}-1 \alpha)$, interleukin-1 $\beta$ (IL$1 \beta$ ), tumor necrosis factor $\alpha$ (TNF- $\alpha$ ) and interleukin-6 (IL-6) $(10,21)$.

The rabbit pyrogen test based on the intravenous injection of a sterile solution was adopted for many years for the quality control of parenteral preparations (14). Alternatives for the refinement of the test, including the comparison of rabbit responses to two E. coli endotoxin preparations, suggested that the temperature cut-off of $0.6^{\circ} \mathrm{C}$ should be decreased to $0.5^{\circ} \mathrm{C}$, as the criterion for a positive result $(9,20)$. However, the rabbit pyrogen test has several drawbacks including low sensitivity, absence of quantitation, unsuitability for some product categories and the involvement of animals $(1,6)$.

The observation that the blood (haemolymph) of the horseshoe crab became clotted in the presence of the bacterial endotoxins gave rise to the Limulus amoebocyte lysate test (LAL), which is specific and sensitive for endotoxins from Gram-

* Corresponding author. Mailing address. Departamento de Farmácia Industrial, Centro de Ciências da Saúde, Universidade Federal de Santa Maria. 97105-900, Santa Maria, RS, Brasil. Tel/Fax: (+5555) 2208805. E-mail: sdalmora@ccs.ufsm.br 
negative bacteria $(11,20)$. However, the test can give falsenegative and false-positive results and, being a test for Gramnegative LPS, it does not detect Gram-positive exotoxins, viruses and fungi $(7,13,16)$. In the LAL test, the LPS-induced reaction can be measured using various approaches, which were adopted together with the rabbit pyrogen test in the collaborative studies that established the $1^{\text {st }}$ and $2^{\text {nd }}$ International Standard for bacterial endotoxins $(15,17)$. However, despite the specification of the LAL test for pharmaceutical products, there remain a number of complex preparations, such as biologicals, without specifications or that cannot be tested by the LAL test (6).

In the context of the development of alternatives for the refinement, replacement and reduction of biological tests, the LAL test and the rabbit pyrogen test are also used for the validation of novel in vitro assays under investigation, based on the use of cell lines, peripheral blood monocytes and whole blood $(5,7,13,16)$.

The aims of the present study were to validate the specifications for the bacterial endotoxins test in parenteral pharmaceutical products, to refine the rabbit pyrogen test, to evaluate the responses of different LAL reagents, and to correlate the results of the two methodologies, thus contributing to the quality control of medicines.

\section{MATERIALS AND METHODS}

\section{Reference standard and reagents}

The $2^{\text {nd }}$ International Standard for bacterial endotoxins, 10,000 EU/vial (WHO 94/580), was kindly donated by the National Institute for Biological Standards and Control (NIBSC), Herts, UK. Limulus amoebocyte lysate, $0.06 \mathrm{EU} / \mathrm{mL}$ was obtained from Endosafe (Charleston; SC, USA), Biowhittaker (Walkersville; MD, USA) and Cape Code (Cape Code; MA, USA). New methylene blue was purchased from Sigma (St. Louis; MO, USA). A number of parenteral pharmaceutical products were used, in some cases different batches of the same product, all within their period of validity. Other reagents and plasticware were purchased as sterile and pyrogen-free and glassware was baked at $250^{\circ} \mathrm{C}$ for $1 \mathrm{~h}$ prior to use.

\section{Rabbit pyrogen test}

This test was carried out according to the literature $(3,20)$, using the New Zealand white rabbit strain.

\section{Limulus amoebocyte lysate test (LAL)}

The bacterial endotoxin limits for the parenteral pharmaceutical products without specifications were calculated as the maximum valid dilution (MVD) $(2,20)$.

\section{Interfering factors test}

The inhibition/enhancement test was performed $(2,20)$ on the sample solutions at a dilution less than the MVD, not containing any detectable endotoxins. The geometric mean endpoint concentration of the solutions was determined using the equation $\mathrm{M}=\operatorname{antilog}\left(\sum e / f\right)$, where: $\sum e$ is the sum of the log endpoint concentrations of the dilution series used, and $f$ is the number of replicate test tubes. If the sensitivity of the lysate determined in the presence of the sample solution under test is not less than $0.5 \lambda$ and not greater than $2 \lambda$, the sample solution does not contain factors which interfere under the experimental conditions.

\section{Gel-clot assay}

The assays were performed in Petri dishes $(2,3,20)$, adjusting the volumes and maintaining constant the relationship between them. Equal volumes of lysate and test solution or standard (usually $10 \mu \mathrm{L}$ ) were added to Petri dishes. The reaction mixture was incubated at $37^{\circ} \mathrm{C}$ for $1 \mathrm{~h}$. A number of two-fold serial dilutions were tested and the gel-clot endpoint was determined by adding $1 \mu \mathrm{L}$ of a $0.2 \%$ new methylene blue solution, observing the mixing (negative reaction) or distribution on the surface of the gel (positive reaction). The endotoxin concentration was calculated by multiplying the reciprocal of the greatest dilution of the test solution that gave a positive endpoint by the sensitivity (to endotoxin) of the lysate preparation; the results were expressed in EU/mL.

\section{Chromogenic assay}

The assay was performed in a microplate at $37 \pm 1^{\circ} \mathrm{C}(2,20)$. Fifty $\mu \mathrm{L}$ of the standard or samples were dispensed into the appropriate microplate wells. Then, $50 \mu \mathrm{L}$ of the Limulus amoebocyte lysate solution were added and the microplate was incubated for $10 \mathrm{~min}$ at $37 \pm 1^{\circ} \mathrm{C}$. One hundred $\mu \mathrm{L}$ of the substrate solution were pipetted and the reaction was stopped after 6 minutes by adding $100 \mu \mathrm{L}$ of $25 \%$ acetic acid. The absorbance was read at $405 \mathrm{~nm}$ in a microplate reader and a standard curve plotted. The results were expressed in EU/mL.

\section{RESULTS}

\section{Rabbit pyrogen test}

The dose-response curve of the $2^{\text {nd }}$ International Standard for bacterial endotoxins was obtained by recording the rise in temperature at 15 minutes intervals for three hours. The regression line was calculated and the concentrations that produced a temperature rise of $0.5^{\circ} \mathrm{C}$ and $0.6^{\circ} \mathrm{C}$ were calculated as $13.81 \mathrm{EU} / \mathrm{mL} / \mathrm{kg}$ and $18.57 \mathrm{EU} / \mathrm{mL} / \mathrm{kg}$, respectively (Fig. 1).

\section{Limulus amoebocyte lysate test (LAL), gel-clot}

The labeled reagent LAL sensitivity of $0.06 \mathrm{EU} / \mathrm{mL}$ was confirmed before carrying out the assays. The interfering factors test was performed for the products without specifications (Table 1), at dilutions not exceeding the MVD spiked with the $2^{\text {nd }}$ International Standard, and the samples returned positive 
results, thereby enabling the determination of the minimum valid dilution of the sample free of interference and the endotoxin content in EU/mL.

The comparative results of LAL reagents using the gel-clot endpoint revealed interference with the $\beta$-glucan-reactive LAL reagent for ampicillin samples and erythropoietin $\mathrm{C}$, which gave false-positive results (Table 2).

The LAL gel-clot test, more widely used as a qualitative or semi-quantitative test, was compared to the chromogenic, quantitative assay (Table 3) and produced comparable results for all samples with the exception of methylprednisolone, which gave a lower value for the chromogenic method.
The comparative evaluation of pyrogens by the qualitative rabbit pyrogen test and the semi-quantitative LAL test showed a contamination level that, in most cases, was lower than the sensitivity of the lysate used (Table 4); furthermore, there was good correlation within the two assays.

\section{DISCUSSION}

The rabbit pyrogen test was studied in the context of the importance of alternatives that could contribute towards its refinement. A dose of $13.81 \mathrm{EU} / \mathrm{mL} / \mathrm{kg}$ of the $2^{\text {nd }}$ International Standard for bacterial endotoxins was identified as that which

Table 1. Inhibition/enhancement test of pharmaceutical products, by the Limulus amoebocyte lysate (LAL) assay, with a sensitivity of $0.06 \mathrm{EU} / \mathrm{mL}$.

\begin{tabular}{lccccc}
\hline \multicolumn{1}{c}{ Products } & $\begin{array}{c}\text { Endotoxins limit } \\
\text { calculated }\end{array}$ & $\begin{array}{c}\text { Maximum } \\
\text { valid dilution }\end{array}$ & $\begin{array}{c}\text { Sample } \\
\text { test }\end{array}$ & $\begin{array}{c}\text { Minimum } \\
\text { valid dilution }\end{array}$ & $\begin{array}{c}\text { Geometric } \\
\text { mean EU/mL }\end{array}$ \\
\hline Ciprofloxacin $2 \mathrm{mg} / \mathrm{mL}$ & $0.87 \mathrm{EU} / \mathrm{mg}$ & $1: 29$ & -- & $1: 16$ & 0.06 \\
Ketoprofen $100 \mathrm{mg} / 2 \mathrm{~mL}$ & $3.50 \mathrm{EU} / \mathrm{mg}$ & $1: 2917$ & -- & $1: 32$ & 0.03 \\
Diclofenac $75 \mathrm{mg} / 3 \mathrm{~mL}$ & $4.70 \mathrm{EU} / \mathrm{mg}$ & $1: 1958$ & -- & $1: 64$ & 0.03 \\
Dipyrone $500 \mathrm{mg} / \mathrm{mL}$ & $0.70 \mathrm{EU} / \mathrm{mg}$ & $1: 5833$ & -- & $1: 10$ & 0.03 \\
Erythropoietin $2000 \mathrm{IU} / \mathrm{vial}$ & $2.50 \mathrm{EU} / 2000 \mathrm{IU}$ & $1: 42$ & -- & $1: 2$ & 0.03 \\
recG-CSF 300 mcg/vial & $2 \mathrm{EU} / \mathrm{mL}$ & $1: 33$ & -- & $1: 8$ & 0.06 \\
Calcium folinate $50 \mathrm{mg} / 5 \mathrm{~mL}$ & $0.60 \mathrm{EU} / \mathrm{mg}$ & $1: 100$ & -- & $1: 1$ & 0.04 \\
Fluconazol $2 \mathrm{mg} / \mathrm{mL}$ & $2.33 \mathrm{EU} / \mathrm{mg}$ & $1: 78$ & -- & $1: 2$ & 0.06 \\
Mesna & $0.87 \mathrm{EU} / \mathrm{mg}$ & $1: 1458$ & -- & $1: 32$ & 0.06 \\
Midazolam $50 \mathrm{mg} / 10 \mathrm{~mL}$ & $35 \mathrm{EU} / \mathrm{mg}$ & $1: 2917$ & -- & $1: 64$ & 0.06 \\
Pantoprazol $40 \mathrm{mg} / 10 \mathrm{~mL}$ & $8.75 \mathrm{EU} / \mathrm{mg}$ & $1: 583$ & -- & $1: 256$ & 0.03 \\
Tenoxican $40 \mathrm{mg} / \mathrm{mL}$ & $8.75 \mathrm{EU} / \mathrm{mg}$ & $1: 2917$ & -- & $1: 640$ & 0.03 \\
\hline
\end{tabular}

(-) Negative response.

Table 2. Results of pharmaceutical products by the LAL gel-clot test with different reagents.

\begin{tabular}{|c|c|c|c|c|}
\hline \multirow[t]{2}{*}{ Products } & \multirow{2}{*}{$\begin{array}{c}\text { Endotoxin limit } \\
\text { EU/mL }\end{array}$} & \multicolumn{3}{|c|}{ Reagent Limulus amoebocyte lysate (LAL) } \\
\hline & & $\stackrel{\mathbf{I}^{\mathbf{a}}}{\mathbf{E U} / \mathbf{m L}}$ & $\underset{\mathbf{E U} / \mathbf{m L}}{I^{\mathbf{a}}}$ & $\underset{\mathbf{E U} / \mathrm{mL}^{\mathrm{b}}}{\mathrm{II}^{2}}$ \\
\hline Ampicillin $1000 \mathrm{mg} / 5 \mathrm{mLA}$ & 30 & $153.60-307.20$ & $76.80-153.60$ & $<0.06$ \\
\hline Ampicillin $1000 \mathrm{mg} / 5 \mathrm{~mL} \mathbf{B}$ & 30 & $30.72-61.44$ & $15.36-30.72$ & $<0.06$ \\
\hline Insulin $100 \mathrm{U} / \mathrm{mL}$ & 80 & $<0.06$ & $<0.06$ & $<0.06$ \\
\hline Erythropoietin 2000 IU/vial A & 2.50 & $491.50-983$ & $491.50-983$ & $245.75-491.50$ \\
\hline Erythropoietin 4000 IU/vial C & 5 & $3.84-7.68$ & $7.68-15.36$ & $<0.06$ \\
\hline Gentamicin $80 \mathrm{mg} / 2 \mathrm{~mL}$ & 68 & $<0.06$ & $<0.06$ & $<0.06$ \\
\hline Oxacillin $500 \mathrm{mg} / 5 \mathrm{~mL}$ & 20 & $<0.06$ & $<0.06$ & $<0.06$ \\
\hline Heparin $5000 \mathrm{IU} / \mathrm{mL}$ & 150 & $<0.06$ & $<0.06$ & $<0.06$ \\
\hline
\end{tabular}

${ }^{a} \beta$-glucans-reactive; ${ }^{\mathrm{b}} \beta$-glucans non-reactive. 
Table 3. Results of pharmaceutical products by the LAL gel-clot and Chromogenic tests.

\begin{tabular}{lccc}
\hline \multirow{2}{*}{ Products } & \multicolumn{2}{c}{ LAL test } & \\
\cline { 2 - 3 } & $\begin{array}{c}\text { Gel-clot } \\
\text { EU/mL }\end{array}$ & $\begin{array}{c}\text { Chromogenic } \\
\text { EU/mL }\end{array}$ & \\
\hline Cytarabine $100 \mathrm{mg} / 5 \mathrm{~mL}$ & $<0.06$ & 0.06 & Pass \\
Diclofenac $75 \mathrm{mg} / 3 \mathrm{~mL}$ & $<0.06$ & $<0.06$ & Pass \\
Ranitidine $25 \mathrm{mg} / \mathrm{mL}$ & $1.20-2.40$ & 1.37 & Pass \\
Heparin $5000 \mathrm{IU} / \mathrm{mL}$ & $<0.06$ & $<0.06$ & Pass \\
Erythropoietin $4000 \mathrm{IU} / \mathrm{vial}$ B & $0.48-0.96$ & 0.84 & Pass \\
Furosemide $10 \mathrm{mg} / \mathrm{mL}$ & $<0.06$ & $<0.06$ & Pass \\
Methylprednisolone 500 mg/5 mL & $245.75-491.50$ & 146 & Fail \\
Insulin 100 U/mL & $<0.06$ & $<0.06$ & Pass \\
Vancomycin $500 \mathrm{mg} / 5 \mathrm{~mL}$ & $2.40-4.80$ & 3.20 & Pass \\
Dexamethasone $4 \mathrm{mg} / \mathrm{mL}$ & $<0.06$ & $<0.06$ & Pass \\
Oxacillin 500 mg/5 mL & $<0.06$ & $<0.06$ & Pass \\
Gentamicin $80 \mathrm{mg} / \mathrm{mL}$ & $<0.06$ & $<0.06$ & Pass \\
Metoclopramide $10 \mathrm{mg} / \mathrm{mL}$ & $<0.06$ & $<0.06$ & Pass \\
recG-CSF 300 mcg/vial & $<0.06$ & $<0.06$ & Pass \\
Vitamin K 10 mg/mL & $<0.06$ & $<0.06$ & Pass \\
\hline
\end{tabular}

Table 4. Results of the parenteral pharmaceutical products by the rabbit pyrogen test and Limulus amoebocyte lysate test.

\begin{tabular}{|c|c|c|c|}
\hline Products & $\begin{array}{c}\text { Endotoxin limit } \\
\text { EU/mL }\end{array}$ & LAL test & $\begin{array}{c}\text { Rabbit } \\
\text { test }\end{array}$ \\
\hline Amikacin $500 \mathrm{mg} / 2 \mathrm{~mL}$ & $0.33 \mathrm{EU} / \mathrm{mg}$ & $<0.06$ & Pass \\
\hline Ampicillin $1000 \mathrm{mg} / 5 \mathrm{~mL} \mathbf{A}$ & $0.15 \mathrm{EU} / \mathrm{mg}$ & $<0.06$ & Pass \\
\hline Ampicillin $1000 \mathrm{mg} / 5 \mathrm{~mL}$ B & $0.15 \mathrm{EU} / \mathrm{mg}$ & $<0.06$ & Pass \\
\hline Ketoprofen $100 \mathrm{mg} / 2 \mathrm{~mL}$ & $3.50 \mathrm{EU} / \mathrm{mg} *$ & $<0.06$ & Pass \\
\hline Ciprofloxacin $2 \mathrm{mg} / \mathrm{mL}$ & $0.87 \mathrm{EU} / \mathrm{mg}^{*}$ & $<0.06$ & Pass \\
\hline Cytarabine $100 \mathrm{mg} / 5 \mathrm{~mL}$ & $0.07 \mathrm{EU} / \mathrm{mg}$ & $<0.06$ & Pass \\
\hline Dexamethasone $4 \mathrm{mg} / \mathrm{mL}$ & $31.30 \mathrm{EU} / \mathrm{mg}$ & $<0.06$ & Pass \\
\hline Diclofenac $75 \mathrm{mg} / 3 \mathrm{~mL}$ & 4.70 EU/mg* & $<0.06$ & Pass \\
\hline Dipyrone $500 \mathrm{mg} / \mathrm{mL}$ & $0.70 \mathrm{EU} / \mathrm{mg} *$ & $<0.06$ & Pass \\
\hline Enoxaparin $100 \mathrm{mg} / \mathrm{mL}$ & $0.01 \mathrm{EU} / \mathrm{U}$ anti-Xa & $<0.06$ & Pass \\
\hline Erythropoietin 2000 IU/vial A & 2.50 EU/2000 IU* & $245.75-491.50$ & Fail \\
\hline Erythropoietin 4000 IU/vial B & $5 \mathrm{EU} / 4000 \mathrm{IU}^{*}$ & $0.48-0.96$ & Pass \\
\hline Erythropoietin 4000 IU/vial C & $5 \mathrm{EU} / 4000 \mathrm{IU}^{*}$ & $<0.06$ & Pass \\
\hline recG-CSF 300 mcg/vial & $2 \mathrm{EU} / \mathrm{mL}^{*}$ & $<0.06$ & Pass \\
\hline Fluconazol $2 \mathrm{mg} / \mathrm{mL}$ & $2.33 \mathrm{EU} / \mathrm{mg} *$ & $<0.06$ & Pass \\
\hline Calcium folinate $50 \mathrm{mg} / 5 \mathrm{~mL}$ & $0.60 \mathrm{EU} / \mathrm{mg} *$ & $<0.06$ & Pass \\
\hline Gentamicin $80 \mathrm{mg} / 2 \mathrm{~mL}$ & $1.7 \mathrm{EU} / \mathrm{mg}$ & $<0.06$ & Pass \\
\hline Mesna & $0.87 \mathrm{EU} / \mathrm{mg} *$ & $<0.06$ & Pass \\
\hline Methylprednisolone $500 \mathrm{mg} / 5 \mathrm{~mL}$ & $0.17 \mathrm{EU} / \mathrm{mg}$ & $245.75-491.50$ & Fail \\
\hline Midazolam 50 mg/10 mL & $35 \mathrm{EU} / \mathrm{mg} *$ & $<0.06$ & Pass \\
\hline Oxacillin $500 \mathrm{mg} / 5 \mathrm{~mL}$ & $0.20 \mathrm{EU} / \mathrm{mg}$ & $<0.06$ & Pass \\
\hline Pantoprazol $40 \mathrm{mg} / 10 \mathrm{~mL}$ & $8.75 \mathrm{EU} / \mathrm{mg}$ * & $<0.06$ & Pass \\
\hline Ranitidine $25 \mathrm{mg} / \mathrm{mL}$ & $7 \mathrm{EU} / \mathrm{mg}$ & $1.20-2.40$ & Pass \\
\hline Saline solution $0.9 \%$ & $0.50 \mathrm{EU} / \mathrm{mL}$ & $48-96$ & Fail \\
\hline Glucose $0.5 \%$ & $0.50 \mathrm{EU} / \mathrm{mL}$ & $1920-3840$ & Fail \\
\hline Tenoxican $40 \mathrm{mg} / 2 \mathrm{~mL}$ & 8.75 EU/mg* & $<0.06$ & Pass \\
\hline Vancomycin $500 \mathrm{mg} / 5 \mathrm{~mL}$ & $0.33 \mathrm{EU} / \mathrm{mg}$ & $2.40-4.80$ & Pass \\
\hline
\end{tabular}

*Endotoxin limits calculated - DFI/UFSM. produced a $0.5^{\circ} \mathrm{C}$ rise in temperature (Fig. 1); this value, although variable according to the strain of the animals used, is recommended as a criterion for positive responses $(9,17)$. Despite its shortcomings, the test is recommended by the Pharmacopoeias $(2,3,20)$, and it is important for the validation of new in vitro assays under development $(4,7,16)$.

The Limulus amoebocyte lysate test (LAL) is recommended $(2,3,20)$ for the quality control of medicines, but the specifications need to be validated for new biological medicines, which are produced mainly through recombinant DNA technology (Table 1). The validation studies indicated geometric means between $\geq 0.5 \lambda$ and $\leq$ $2 \lambda$, with recovery between 50 and $200 \%(2,20)$. This test is important in order to eliminate false-negative and false-positive results $(13,14,16)$ caused by the interference of the active substance or components of the final product formulation. Thus, the establishment and validation of the specifications for the quality control of the medicinal products tested is recommended.

The evaluation of pharmaceutical products using different LAL reagents (Table 2) showed that some batches of ampicillin and human recombinant erythropoietin, which gave positive results with the $\beta$-glucan-reactive reagents, gave negative results when analyzed by the $\beta$-glucan nonreactive reagent, thus demonstrating interference. These observations are important for quality control, assisting in the selection of the LAL reagent and the evaluation of the results obtained for the samples $(12,19)$. It should be recalled that this difference between the reagents could result in the incorrect rejection of batches, mainly when the response levels are near to the maximum valid dilution specified for test compliance.

The comparative tests of pharmaceutical products using the LAL test with chromogenic and gel-clot endpoints gave similar results (Table $3)$. These experiments are important considering that the gel-clot method, being less expensive and easier to perform, has been used routinely for the quality control of medicines with limits declared as endotoxin units $(2,3,20)$. In the present study, it was also used for comparison with the rabbit pyrogen test, showing good agreement (Table 4) and demonstrating the importance of both methodologies for the development and validation of new pyrogens tests.

Our results show that the rabbit pyrogen test, which is being gradually replaced by the LAL test, 


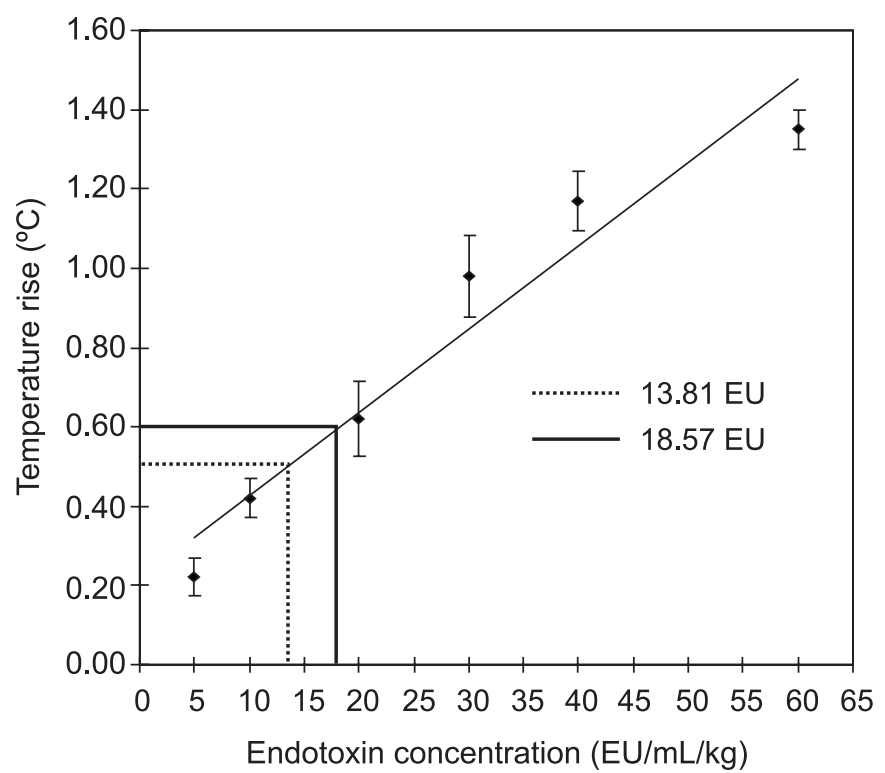

Figure 1. Linear regression line calculated from three independent assays of the $2^{\text {nd }}$ International Standard for Bacterial endotoxins. Concentrations necessary to produce a temperature rise of $0.5^{\circ} \mathrm{C}(\ldots)$ and $0.6^{\circ} \mathrm{C}(-) . \mathrm{Y}=0.21+0.021 \mathrm{X}$ $\left(\mathrm{R}^{2}=0.92 ; p>0.05\right.$ for $\left.\mathrm{n}=9\right)$.

continues to be valid and necessary. However, the LAL test validation and the specifications established for the new recombinant biologicals will contribute towards assuring the quality and safety of parenteral pharmaceutical products.

\section{ACKNOWLEDGEMENTS}

The authors wish to thank Dr. Stephen Poole from NIBSC for his suggestions and CAPES for the financial support.

\section{RESUMO}

\section{Avaliação comparativa de testes de pirogênios em produtos farmacêuticos}

Realizou-se a comparação de metodologia para avaliação de pirogênios em produtos farmacêuticos. Otimizou-se o teste da hipertermia em coelhos elaborando a curva dose-resposta com o $2^{\circ}$ Padrão Internacional de endotoxinas bacterianas, com base na qual determinou-se a concentração de $13,81 \mathrm{UE} / \mathrm{mL}$ por $\mathrm{kg}$ de peso corporal, necessária para produzir aumento de temperatura de $0,5^{\circ} \mathrm{C}$. Observou-se que o limite de $0,5^{\circ} \mathrm{C}$ forneceu resultados comparáveis com as doses pirogênicas para o homem. Padronizou-se o teste do lisado de amebócitos do Limulus (LAL) com determinação do ponto final cromogênico e por geleificação, que foram utilizados para a avaliação de produtos farmacêuticos obtendo-se resultados concordantes. Avaliaram-se as respostas de reagentes LAL reativos e nãoreativos a $\beta$-glicanos, observando diferenças que poderiam reprovar amostras com base em resultados falso-positivos. Executou-se o teste de interferências, validou-se o procedimento e estabeleceu-se a máxima diluição válida para produtos farmacêuticos sem especificações farmacopéicas. Os resultados enfatizam a importância e as limitações dos ensaios preconizados para avaliação da pureza e controle da qualidade de produtos farmacêuticos parenterais, contribuindo para aprimorar as metodologias existentes no contexto da redução e substituição dos modelos animais.

Palavras-chave: endotoxinas bacterianas, lisado do amebócito do Limulus, pirogênios, hipertermia em coelhos

\section{REFERENCES}

1. Castle, P. Alternatives to animal testing: achievements and recent developments in the European Pharmacopoeia. Dev. Biol. Stand., 86:21-29, 1996.

2. European Pharmacopoeia. $4^{\text {th }}$ ed., Strasbourg: European Department for the Quality of Medicines, 2002.

3. Farmacopéia Brasileira. 4 ed., Atheneu: São Paulo, 1988.

4. Fennrich, S.; Fischer, M.; Hartung, T.; Lexa, P.; Montag-Lessing, T.; Sonntag, H.G.; Weigandt, M.; Wendel, A. Detection of endotoxins and others pyrogens using human whole blood. Dev. Biol. Stand., 101: 131-139, 1999.

5. Hansen, E.W.; Christensen, J.D. Comparison of cultured human mononuclear cells, Limulus amoebocyte lysate and rabbits in the detection of pyrogens. J. Clin. Pharm. Ther., 15: 425-433, 1990.

6. Hartung, T.; Aaberge, I.; Berthold, S.; Carlin, G.; Charton, E.; Coecke, S.; Fennrich, S.; Matthias, F.; Gommer, M.; Halder, M.; Haslow, K.; Jahnke, M.; Montag-Lessing, T.; Poole, S.; Schechtman, L.; Wendel, A.; Werner-Felmayer, G. Novel pyrogen tests based on the human fever reaction. ATLA, 29:99-123, 2001.

7. Hartung, T.; Wendel, A. Detection of pyrogens using human whole blood. "In Vitro" Toxicology, 9: 353-359, 1996.

8. Henderson, B.; Poole, S.; Wilson, M. Bacterial modulins: a novel class of virulence factors which cause host tissue pathology by inducing cytokine synthesis. Microbiol. Res., 60: 316-341, 1996.

9. Hochstein, H.D.; Munsom, T.E.; Outschoorn, A.S. Comparison of rabbit responses of two E. coli endotoxin preparations in the USP rabbit test. Pharmacopoeial Forum, Março-Abril: 346-351, 1990 .

10. Kluger, M.J. Fever: role of pyrogens and cryogens. Physiol. Rev., 71: 93-127, 1990.

11. Levin, J.; Bang, F.B. The role of endotoxin in the extracellular coagulation of Limulus blood. Bull Johns Hopkin Hosp., 115: 265274, 1964.

12. Petri, E.; Van de Ploeg, A.; Habermaier, B.; Fennrich, S. Improved detection of pyrogenic substances on polymer surfaces with an ex vivo human whole-blood assay in comparison to the Limulus amoebocyte lysate test. In: Balls, M.; van Zeller, A.-M.; Halder, M.E. (eds.). Progress in the reduction, refinement and replacement of animal experimentation. Elsevier, Amsterdam, 2000, p.339345 .

13. Pool, E.J.; Johaar, G.; James, S.; Petersen, I.; Bouic, P. The detection of pyrogens in blood products using an ex vivo whole blood culture assay. J. Immunoassay., 19: 95-111, 1998. 
14. Poole, S. Pyrogen testing of polypeptide and protein drugs. In Hider, R.C.; Barlow, D. (eds.). Polypeptide and protein drugs: production, characterization and formulation. Chichester: Ellis Horwood, 1991, p.146-153.

15. Poole, S.; Dawson, P.; Gaines Das, R.E. The second international standard for endotoxins: calibration in an international collaborative study. J. Endotox. Res., 4:221-231, 1997.

16. Poole, S.; Gaines Das, R.E. Towards a 'human pyrogen test'. Eur. $J$ Parenter. Sci., 6: 63-64, 2001.

17. Poole, S.; Mussett, M.V. The international standard for endotoxin: evaluation in an international collaborative study. J. Biol. Stand., 17: $161-171,1989$.
18. Rietschel, E.T.; Kirikae, T.; Schade, F.U.; Mamat, U.; Schmidt, G.; Loppnow, H.; Ulmer, A.J.; Zahringer, U.; Seydel, U.; Di Padova, F.; Schreier, M.; Brade, H. Bacterial endotoxin: molecular relationships of structure to activity and function. FASEB J., 8: 217-225, 1994.

19. Roslansky, P.F.; Novitsky, T.J. Sensitivity of Limulus amoebocyte lysate (LAL) to LAL-reactive glucans. J. Clin. Microbiol., 29: $2477-$ 2483, 1991

20. The United States Pharmacopoeia 25, Rockville, The United States Pharmacopeial Convention, 2001.

21. Ulevitch, R.J.; Tobias, P.S. Receptor-dependent mechanisms of cell stimulation by bacterial endotoxin. Ann. Rev. Immunol., 13: 437$457,1995$. 